\title{
Patient safety culture from the perspective of all the workers of a general hospital
}

\author{
Cultura de segurança do paciente na perspectiva de todos \\ os trabalhadores de um hospital geral \\ Cultura de seguridad del paciente desde la perspectiva de \\ todos los trabajadores de un hospital general \\ Adriane Cristina Bernat Kolankiewicz \\ Catiele Raquel Schmidt ${ }^{\mathrm{b}, \mathrm{c}}$ \\ Rhanna Emanuela Fontenele Lima de Carvalho ${ }^{d}$ \\ Jacinta Spies ${ }^{e}$ (i) \\ Sandra Dal Pai ${ }^{\mathrm{a}, \mathrm{e}}$ \\ Elisiane Lorenzini ${ }^{f}$
}

\begin{abstract}
How to cite this article: Kolankiewicz ACB, Schmidt CR, Carvalho REFL, Spies J, Dal Pai S, Lorenzini E. Patient safety culture from the perspective of all the workers of a general hospital. Rev Gaúcha Enferm. 2020;41:e20190177. doi: https://doi.org/10.1590/19831447.2020.20190177
\end{abstract}

a Universidade Regional do Noroeste do Estado do Rio Grande do Sul (UNIJUU).). Programa de Pós-Graduação Strictu Sensu em Atenção Integral à Saúde. ljuú, Rio Grande do Sul, Brasil.

${ }^{6}$ Universidade do Estado de Santa Catarina (UDESC). Florianópolis, Santa Catarina, Brasil.

Escola de Saúde Pública de Florianópolis. Residência Multiprofissional em Saúde da Familia. Florianópolis, Santa Catarina, Brasil.

${ }^{d}$ Universidade Estadual do Ceará (UECE). Programade Pós-Graduação Strictu Sensu Cuidados Clínicos em Enfermagem e Saúde e Mestrado Profissional em Saúde da Criança e do Adolescente. Fortaleza, Ceará, Brasil.

• Hospital Vida e Saúde. Santa Rosa, Rio Grande do Sul, Brasil.

Universidade Federal de Santa Catarina (UFSC), Departamento de Enfermagem, Programa de PósGraduação em Enfermagem. Florianópolis, Santa Catarina, Brasil.

\section{ABSTRACT}

Objective: To assess the patient safety culture among the workers of a hospital institution in southern Brazil.

Method: This is a cross-sectional study, which was performed with 630 hospital workers, at Santa Rosa, Rio Grande do Sul, Brazil, through the Safety Attitudes Questionnaire tool, in the month of April 2017.

Results: We found positive scores in all the safety culture domains, except for the perceived stress domain.

Conclusion: Job satisfaction and teamwork spirit showed better scores for nursing and health professionals, when compared to the support team. Schooling, gender, operation time and the choice of workplace positively influenced the safe atmosphere.

Keywords: Organizational culture. Admitting department, hospital. Patient safety. Health management. Patient care team.

\section{RESUMO}

Objetivo: Avaliar a cultura de segurança do paciente entre todos os trabalhadores de uma instituição hospitalar no sul do Brasil.

Método: Estudo transversal, realizado com 630 trabalhadores de um hospital de Santa Rosa, no Rio Grande do Sul, Brasil, por meio do instrumento Safety Attitudes Questionnaire, no mês de abril de 2017.

Resultados: Encontraram-se escores positivos em todos os domínios da cultura de segurança, exceto para o domínio percepção do estresse.

Conclusão: A satisfação do trabalho e o clima de trabalho em equipe demonstraram melhores escores para profissionais da enfermagem e da área da saúde, se comparado à equipe de apoio. Escolaridade, gênero, tempo de atuação e a escolha pela unidade de trabalho influenciaram positivamente 0 clima de segurança.

Palavras-chave: Cultura organizacional. Serviço hospitalar de admissão de pacientes. Segurança do paciente. Gestão em saúde. Equipe de assistência ao paciente.

\section{RESUMEN}

Objetivo: Evaluar la cultura de seguridad del paciente entre los trabajadores de una institución hospitalaria de Santa Rosa, Río Grande del Sur, Brasil.

Método: Estudio transversal, el cual se desarrolló con un equipo multidisciplinario de una institución hospitalaria, mediante el instrumento Safety Attitudes Questionnaire, en el mes de abril de 2017.

Resultados: Se encontraron puntuaciones positivas en todos los dominios de la cultura de seguridad, excepto para el dominio sobre la percepción del estrés.

Conclusión: La satisfacción laboral y el clima de trabajo en equipo demostraron mejores puntuaciones para profesionales de la enfermería y del área de la salud, en comparación con el equipo de apoyo. La escolaridad, el género, el tiempo activo en la profesión y la elección por el sitio de trabajo influenciaron el clima de seguridad de manera positiva.

Palabras clave: Cultura organizacional. Servicio de admisión en hospital. Seguridad del paciente. Gestión en salud. Grupo de atención al paciente. 


\section{INTRODUCTION}

Errors and Adverse Events (AEs), considered preventable, are the third leading cause of death in the United States ${ }^{(1)}$. In the United Kingdom, these errors cost the National Health Service around 2 billion annually ${ }^{(2)}$.

In Brazil, it is estimated that every 3 minutes, 2.47 Brazilians die in a public or private hospital as a result of AEs. It is estimated that if AEs associated with hospital care were a cause of death group registered in the International Classification of Diseases (ICD), the mortality associated with these events would be between $1^{\text {st }}$ and $5^{\text {th }}$ position, therefore, one of the most frequent causes of death ${ }^{(3)}$. Globally, strategies are currently being discussed for making health care harmless ${ }^{(1)}$ and not just reducing its occurrence to an acceptable minimum.

Brazil is a member of the World Health Organization (WHO) World Patient Safety Alliance and the Federal Government has been implementing measures to improve quality and to promote patient safety, which is still in its early stages in health care institutions across the country ${ }^{(4)}$. In April 2013, the National Patient Safety Program (Programa Nacional de Segurança do Paciente, PNSP) was implemented, which, among other objectives, aims to promote the culture of patient safety in health institutions. This is a concept that encompasses the set of individual and group attitudes, perceptions, values, and competencies and behavioral patterns that determine commitment, style and proficiency regarding patient safety and health management issues in a safe and fruitful institution ${ }^{(5)}$.

The safety culture of an institution can be known from the safe atmosphere analysis. This is the temporal assessment, which is obtained through the application of validated questionnaires that measure the professionals' perception of patient safety in their workplace(6).

Among the instruments, there is the Safety Attitudes Questionnaire $(S A Q)$, which aims to measure the perception of a safe atmosphere across six domains: Teamwork spirit, Safe atmosphere, Job Satisfaction, Perception of Unit and Hospital Management, Working Conditions, and Stress Recognition. The atmosphere is considered positive when the score is $\geq 75^{(7)}$.

Its results also make it possible to analyze possible relations, correlations or associations with hospital indicators, such as: mean permanence, pressure injury rates and hospital infection rates, among others ${ }^{(8)}$. Several studies on the subject have been published internationally and nationally. Results have shown overall SAQ scores with mean values of $69^{(9)}, 65.1^{(10)}$, and $68^{(11)}$.

It is noteworthy that the literature lacks studies that explain why health professionals often assess negatively the safe environment in healthcare institutions. Therefore, it is noted that there is a gap in the literature, aggravated by the fact that most studies have focused only on specific areas of the hospital, or even address only some professional groups, especially nursing. That is, based on the current literature, for example, it is not possible to infer about the demographic or work characteristics of other professionals working in hospital institutions, which may or may not correlate with the results of an institution's safe environment.

Thus, it is reasoned that knowing these factors, through studies involving all professionals of an institution, contributes greatly to identify these gaps. In addition, it is a subsidy for future strategies that can be developed aiming at improving the safety culture, which must be designed primarily to meet the previously identified needs, with specific public and area. Thus, the execution of this study is justified, which had the following as a guiding question: what is the patient safety culture from the perspective of all workers in a hospital institution? Thus, the aim of the study was to evaluate the patient safety culture among all workers of a hospital institution in southern Brazil.

\section{METHOD}

A cross-sectional study conducted with all the professionals working in a hospital in Santa Rosa, Rio Grande do Sul, Brazil, with an operating capacity of 500 beds.

The criteria for participating in the study were the following: working at least one month in the unit with a weekly workload of 20 hours or more. Professionals who were on sick leave and vacation at the time of data collection were excluded. 630 workers participated in the study, from a total of 698 professionals.

Data collection was carried out in April 2017, by a master student, the project coordinator and two previously qualified undergraduate research assistants. The training included the reading and discussion of the SAQ developed in Tex$a s^{(6)}$ and validated for use in Brazi ${ }^{(9)}$. The approach of the professionals took place in their working units, through an invitation. After acceptance, the participant signed the Free and Informed Consent Form (FICF). The research assistants remained in the room in order to clarify doubts and receive the completed questionnaire. This organization took place in the three work shifts.

The instrument consists of two parts: the first has 41 items that cover six domains, namely: safe environment, teamwork spirit, job satisfaction, perception of unit and hospital management, working conditions and recognition of stress ${ }^{(9)}$. The second part was adapted by the researchers and aims to obtain variables to characterize the professional 
(gender, professional category, education, time in the institution, chose to work in another unit and if he has another employment bond).

The answers to the questions follow a five-point Likert scale: strongly disagree (0), slightly disagree (25), neutral (50), slightly agree (75), strongly agree $(100)^{(6)}$. The questionnaire includes reverse questions (2, 11 and 36), where the score reverses from 100 to zero. The final instrument score ranges from 0 to 100, where zero represents the worst perception of the safe environment and 100 represents the best. The cutoff point considered positive is when the total score is greater than or equal to $75^{(6)}$.

For better data analysis, the study participants were classified into three independent groups: Nursing staff (nurses, technicians and nursing assistants); support staff (administrative area, kitchen and eating areas, drivers, accountants, doormen, hotel staff and orderlies); other health professionals (doctors, nutritionists, physiotherapists, dentists, radiology technicians, pharmacy assistants, pharmacists, psychologists and social workers).

Performed using the Statistical Package for Social Sciences program, version 20.0. The results were presented by descriptive statistics, absolute and relative distribution ( $\mathrm{n}$ - \%), central tendency measures and variability. To evaluate the symmetry of the data, the Kolmogorov-Smirnov test was applied. The internal consistency of the instrument was assessed using the standardized Cronbach's alpha coefficient

In the comparison of the means between the domains, we used the analysis of variance for repeated measures Bonferroni Post-Hoc, with study of sphericity through the Mauchly test. To compare SAQ domain scores, Student's t-test or Mann Whitney $U$ tests were used for independent groups. When the comparison of scores involved three or more independent groups, analysis of variance was used. The hypothesis of homogeneity of variance was verified by the Levene test and, when rejected, the correction of Brown-Forsythe - Post Hoc Scheffé was used. For the decision on hypothesis testing to be significant, a significance level of $5 \%$ was adopted. The study was approved by the Research Ethics Committee of the institution under CAAE No. 30449514.3.00.

\section{RESULTS}

The response rate of this study was $75 \%$. Of the $230(48.5 \%)$ nursing team professionals, 37 were nurses, 191 nursing technicians and two nursing assistants; in the support team, 197 (41.6\%) answered the questionnaire. Of these, 99 were administrative workers, 24 kitchen and eating areas, 36 cleaning staff, 13 laundry assistants, seven doormen, four hotel staff, seven drivers, two accountants and two orderlies. As for the other health professionals, 47 (9.9\%), four were nutritionists, four physiotherapists, one dentist, seven radiology technicians, 19 pharmacy assistants, four pharmacists, two psychologists, one social worker and five doctors.

As shown in Table 1, all the SAQ domains had a positive score, except for the stress perception domain. The mean score for the job satisfaction domain showed a statistical difference when compared to the other means, except when compared to the mean of the working conditions domain. The overall internal consistency analysis of the SAQ presented an alpha coefficient of 0.859 .

The classification of values considered positive for safety culture $(\geq 75)^{(7)}$ were predominant, with a maximum prevalence of $91.1 \%(n=432)$ in the job satisfaction domain and a minimum of $48.8 \%(n=231)$ in the unit management perception domain.

When comparing the mean scores of the domains between the three professional areas, the results showed that the professionals with the highest level of education had significantly higher mean scores when compared to the ones with lower levels of education. A significant difference was found in the job satisfaction domain $(p<0.001)$, where the mean between nurses and other professionals were significantly higher when compared to the support team group ( $p<0.01$ ). Still, the significant difference was in the comparison of the mean scores of the teamwork spirit domain ( $p=0.022)$, and the safe atmosphere domain, and the support team had a lower mean when compared to other groups, as shown in Table 2. 
Table 1 - Mean, standard deviation, median and Cronbach's alpha of SAQ* domains from the perspective of the multiprofessional team of a hospital. Santa Rosa, RS, Brazil, 2017

\begin{tabular}{|c|c|c|c|c|c|c|}
\hline \multirow[b]{2}{*}{ SAQ* Domains } & \multirow[b]{2}{*}{ Mean } & \multirow[b]{2}{*}{$\begin{array}{l}\text { Standard } \\
\text { deviation }\end{array}$} & \multirow[b]{2}{*}{ Median } & \multicolumn{2}{|c|}{ Classification } & \multirow{2}{*}{$\begin{array}{c}\text { Alpha } \\
\text { Cronbach }\end{array}$} \\
\hline & & & & Low $(<75)$ & High ( $\geq 75)$ & \\
\hline Teamwork spirit & 80.4 & 14.4 & 83.3 & $164(35.1 \%)$ & 303 (63.9\%) & 0.572 \\
\hline Safe environment & 77.8 & 13.8 & 78.6 & $208(43.9 \%)$ & $266(56.1 \%)$ & 0.602 \\
\hline Job satisfaction & 92.7 & 12.1 & 95.0 & 42 (8.9\%) & 432 (91.1\%) & 0.812 \\
\hline Perception of stress & 60.5 & 27.9 & 66.7 & $332(70.3 \%)$ & $338(71.5 \%)$ & 0.802 \\
\hline $\begin{array}{l}\text { Perception of } \\
\text { hospital management }\end{array}$ & 75.2 & 16.1 & 75.0 & 255 (53.8\%) & $219(46.2 \%)$ & 0.583 \\
\hline $\begin{array}{l}\text { Perception of } \\
\text { unit management }\end{array}$ & 75.6 & 17.0 & 75.0 & $242(51.2 \%)$ & $231(48.8)$ & 0.632 \\
\hline Working conditions & 85.7 & 16.4 & 91.7 & 135 (28.5\%) & $338(71.5 \%)$ & 0.552 \\
\hline $\begin{array}{l}\text { Comparison between the } \\
\text { means of the domains }\end{array}$ & $F_{5 ; 2784}=1$ & $n<0001$. & $=0.952+$ & & & \\
\hline
\end{tabular}

Source: Research data, 2017

*Safety Attitudes Questionnaire; $†$ ANOVA for repeated measures $\left[\mathrm{F}_{5 ; 2784}=189.661 ; p<0.001 ;(1-\beta)=0.952\right]$

Table 2 - Mean, standard deviation by area from the perspective of the multi-professional team that works in a hospital. Santa Rosa, RS, Brazil, 2017

\begin{tabular}{|c|c|c|c|c|c|c|c|}
\hline \multirow[t]{2}{*}{ SAQ* Domains } & \multicolumn{2}{|c|}{ Nursing team $(n=230)$} & \multicolumn{2}{|c|}{$\begin{array}{l}\text { Other professionals } \\
\qquad(n=47)\end{array}$} & \multicolumn{2}{|c|}{$\begin{array}{l}\text { Support team } \\
\quad(n=197)\end{array}$} & \multirow[t]{2}{*}{$\mathbf{P}$} \\
\hline & Mean & SDt & Mean & SDt & Mean & SDt & \\
\hline Teamwork spirit & 81.7 & 13.6 & 82.5 & 13.5 & 78.2 & 15.2 & $0.022 \neq$ \\
\hline Safe environment & 79.3 & 12.5 & 81.0 & 11.2 & 75.3 & 15.3 & $0.002 \neq$ \\
\hline Job satisfaction & 94.8 & 8.1 & 94.7 & 7.5 & 89.7 & 15.8 & $<0.001 \S$ \\
\hline Perception of stress & 60.0 & 27.6 & 62.2 & 29.2 & 60.8 & 28.0 & $0.875 \neq$ \\
\hline Hospital Management & 75.9 & 14.6 & 74.8 & 14.4 & 74.4 & 18.2 & $0.634 \S$ \\
\hline Unit Management & 75.2 & 16.6 & 80.2 & 15.2 & 74.9 & 17.8 & $0.146 \S$ \\
\hline Working conditions & 86.6 & 14.5 & 86.1 & 14.6 & 84.5 & 18.7 & $0.423 \S$ \\
\hline
\end{tabular}

Source: Research data, 2017.

*Safety Attitudes Questionnaire; $+S D=$ Standard Deviation; ¥ Anova One Way Test (Welch Correction) - Post Hoc Sheffé; §Anova One Way Test- Post Hoc Tukey

Regarding gender, a significant difference was observed in the perception of stress and management domains, and women had a better perception of factors that can lead to stress, as well as a better perception of management actions regarding patient safety. Regarding the level of schooling, it was evidenced that the professionals with higher education had better scores in the safe atmosphere, job satisfaction, perception of stress and hospital management domains. Tables 3 and 4. 
Table 3 - Mean, standard deviation according to labor characterization from the perspective of the multi-professional team working in a hospital. Santa Rosa, RS, Brazil, 2017

\begin{tabular}{|c|c|c|c|c|c|c|c|c|c|}
\hline \multirow{3}{*}{ Variables } & \multicolumn{9}{|c|}{ SAQ* Domains } \\
\hline & \multirow[t]{2}{*}{$\mathbf{N}+$} & \multicolumn{2}{|c|}{ Teamwork spirit } & \multicolumn{2}{|c|}{$\begin{array}{c}\text { Safe } \\
\text { environment }\end{array}$} & \multicolumn{2}{|c|}{ Job satisfaction } & \multicolumn{2}{|c|}{$\begin{array}{c}\text { Perception } \\
\text { of stress }\end{array}$} \\
\hline & & Mean & $\mathbf{S D} \ddagger$ & Mean & $\mathbf{S D} \neq$ & Mean & SD $\neq$ & Mean & SD \\
\hline \multicolumn{10}{|l|}{ Gender } \\
\hline Female & 380 & 80.3 & 14.7 & 77.6 & 13.6 & 92.4 & 12.6 & 62.1 & 27.8 \\
\hline Male & 87 & 80.9 & 13.0 & 78.8 & 14.7 & 93.7 & 9.8 & 53.7 & 27.4 \\
\hline $\mathrm{P}$ & & \multicolumn{2}{|c|}{$0.726 \S$} & \multicolumn{2}{|c|}{$0.482 \S$} & \multicolumn{2}{|c|}{$0.363 \S$} & \multicolumn{2}{|c|}{$0.011 \|$} \\
\hline \multicolumn{10}{|l|}{ Age (years old) } \\
\hline 18 to 30 & 197 & 79.9 & 14.4 & 78.5 & 13.2 & 92.7 & 10.2 & 58.7 & 25.8 \\
\hline 31 to 50 & 248 & 81.0 & 14.3 & 77.6 & 14.3 & 92.3 & 14.0 & 61.3 & 29.0 \\
\hline 51 years old or more & 29 & 77.7 & 14.5 & 75.5 & 12.6 & 95.2 & 5.1 & 66.5 & 31.2 \\
\hline$P$ & & \multicolumn{2}{|c|}{0.4259} & \multicolumn{2}{|c|}{$0.494 \rrbracket$} & \multicolumn{2}{|c|}{0.490 ฯ } & \multicolumn{2}{|c|}{$0.297^{* *}$} \\
\hline
\end{tabular}

\section{Schooling}

\begin{tabular}{|c|c|c|c|c|c|c|c|c|c|}
\hline $\begin{array}{l}\text { Complete } \\
\text { Elementary School }\end{array}$ & 20 & 77.9 & 13.3 & 70.1 & 12.0 & 89.5 & 17.5 & 58.6 & 30.4 \\
\hline High School & 305 & 78.9 & 15.3 & 77.5 & 13.5 & 92.1 & 12.7 & 57.6 & 28.8 \\
\hline Graduation & 88 & 82.1 & 12.3 & 77.0 & 14.8 & 92.0 & 11.8 & 65.0 & 24.1 \\
\hline $\begin{array}{l}\text { Specialization } \\
\text { (Lato Sensu) }\end{array}$ & 50 & 87.0 & 10.0 & 84.2 & 11.6 & 98.0 & 3.4 & 68.8 & 25.6 \\
\hline Master's degree & 4 & 89.6 & 5.4 & 81.3 & 9.9 & 97.5 & 5.0 & 81.3 & 13.5 \\
\hline $\mathrm{P}$ & & \multicolumn{2}{|c|}{0.0029} & \multicolumn{2}{|c|}{0.0019} & \multicolumn{2}{|c|}{0.0139} & \multicolumn{2}{|c|}{$0.015^{* *}$} \\
\hline \multicolumn{10}{|c|}{ Time in the institution } \\
\hline Less than 1 year & 99 & 83.0 & 14.3 & 80.4 & 12.6 & 93.5 & 10.5 & 56.9 & 27.4 \\
\hline 1 to 3 years & 108 & 82.1 & 13.0 & 78.7 & 13.2 & 90.9 & 13.7 & 59.3 & 27.6 \\
\hline 3 to 5 years & 61 & 76.5 & 14.9 & 77.8 & 12.3 & 92.7 & 7.9 & 64.3 & 25.8 \\
\hline 5 to 10 years & 101 & 79.0 & 15.4 & 76.3 & 14.4 & 93.5 & 10.4 & 59.0 & 27.6 \\
\hline 10 to 20 years & 74 & 81.3 & 13.2 & 76.2 & 14.4 & 92.6 & 16.9 & 62.5 & 29.9 \\
\hline 20 years or more & 31 & 75.6 & 14.7 & 75.5 & 17.4 & 93.2 & 9.6 & 69.2 & 29.6 \\
\hline $\mathrm{P}$ & & \multicolumn{2}{|c|}{0.0159} & \multicolumn{2}{|c|}{0.2299} & \multicolumn{2}{|c|}{0.6599} & \multicolumn{2}{|c|}{$0.246^{* *}$} \\
\hline \multicolumn{10}{|c|}{ Chose to work in the unit } \\
\hline Yes & 370 & 81.0 & 13.8 & 78.7 & 13.6 & 93.3 & 11.6 & 60.2 & 27.4 \\
\hline No & 102 & 78.2 & 16.1 & 74.8 & 13.9 & 90.5 & 13.8 & 61.6 & 29.8 \\
\hline$P$ & & \multicolumn{2}{|c|}{$0.079 \S$} & \multicolumn{2}{|c|}{$0.011 \S$} & \multicolumn{2}{|c|}{$0.040 \S$} & \multicolumn{2}{|c|}{$0.640 \S$} \\
\hline \multicolumn{10}{|c|}{ Has another employment bond } \\
\hline Yes & 64 & 80.7 & 13.7 & 77.2 & 13.3 & 93.8 & 10.3 & 59.4 & 24.8 \\
\hline No & 409 & 80.3 & 14.5 & 77.9 & 13.9 & 92.5 & 12.4 & 60.7 & 28.4 \\
\hline$P$ & & \multicolumn{2}{|c|}{$0.837 \S$} & \multicolumn{2}{|c|}{$0.691 \S$} & \multicolumn{2}{|c|}{$0.436 \S$} & \multicolumn{2}{|c|}{$0.740 \|$} \\
\hline
\end{tabular}

Source: the authors, 2017

*Safety Attitudes Questionnaire; $+\mathrm{N}=$ Total number of participants; $¥ \mathrm{FD}=$ Standard Deviation; §Student's t-test; $\|$; 9 Anova One Way Test - Post Hoc Tukey; **Anova One Way Test (Welch correction) - Post Hoc Sheffé 
Also, regarding time in the institution, the professionals with one to three years of experience and from five to 10 years had significantly higher mean scores when compared to others in the teamwork spirit domain $(p<0.015)$.

When asked if the professional had the opportunity to choose the unit of work, the means were significantly higher in the safe atmosphere $(p=0.011)$, job satisfaction ( $p=0.040)$, and unit management ( $p=0.038$ ) domains for the professionals who had the opportunity to choose the unit in which they would work. No significant differences in means were identified for the age and other employment bonds variables in any of the domains.

Regarding gender, hospital management performance and working conditions, the data show that the perception of male professionals was better when compared to the female assessment of these domains, as shown in Table 4.

Table 4 - Mean, standard deviation according to socio-professional characterization from the perspective of the multiprofessional team working in a hospital. Santa Rosa, RS, Brazil, 2017

\begin{tabular}{|c|c|c|c|c|c|c|c|}
\hline \multirow{3}{*}{ Variables } & \multicolumn{7}{|c|}{ SAQ* Domains } \\
\hline & \multirow{2}{*}{ Nt } & \multicolumn{2}{|c|}{ Hospital Management } & \multicolumn{2}{|c|}{ Unit Management } & \multicolumn{2}{|c|}{ Working conditions } \\
\hline & & Mean & SD $\neq$ & Mean & SDf & Mean & SD $\neq$ \\
\hline \multicolumn{8}{|l|}{ Gender } \\
\hline Female & 380 & 74.1 & 16.1 & 74.7 & 17.0 & 85.3 & 16.9 \\
\hline Male & 87 & 80.0 & 15.4 & 79.2 & 16.6 & 87.3 & 13.7 \\
\hline$P$ & & \multicolumn{2}{|c|}{$0.002 \S$} & \multicolumn{2}{|c|}{$0.026 \S$} & \multicolumn{2}{|c|}{$0.291 \S$} \\
\hline \multicolumn{8}{|c|}{ Age (years old) } \\
\hline 18 to 30 & 197 & 74.0 & 16.4 & 74.3 & 18.1 & 85.9 & 15.5 \\
\hline 31 to 50 & 248 & 75.5 & 16.2 & 76.2 & 16.4 & 85.1 & 17.3 \\
\hline 51 or more & 29 & 80.6 & 12.9 & 78.1 & 14.6 & 88.8 & 14.1 \\
\hline$P$ & & \multicolumn{2}{|c|}{$0.103 \|$} & \multicolumn{2}{|c|}{$0.346 \|$} & \multicolumn{2}{|c|}{$0.491 \|$} \\
\hline
\end{tabular}

\section{Schooling}

\begin{tabular}{lccccccc}
\hline $\begin{array}{l}\text { Complete } \\
\text { Elementary School }\end{array}$ & 20 & 82.5 & 15.6 & 77.6 & 14.9 & 88.3 & 14.7 \\
\hline High School & 305 & 74.5 & 16.3 & 75.3 & 17.5 & 85.9 & 16.6 \\
\hline Graduation & 88 & 73.9 & 16.0 & 74.4 & 17.1 & 84.3 & 17.2 \\
\hline Specialization & 50 & 79.4 & 14.6 & 79.3 & 14.5 & 84.8 & 15.7 \\
\hline Master's degree & 4 & 82.5 & 9.6 & 73.3 & 12.6 & 79.2 & 8.4 \\
\hline$P$ & \multicolumn{2}{c}{$\mathbf{0 . 0 4 8}$} & & & $0.514 \|$ & $0.763 \|$ & \\
\hline
\end{tabular}

Time in the institution

\begin{tabular}{lccccccc}
\hline Less than 1 year & 99 & 75.7 & 15.4 & 77.0 & 16.8 & 86.2 & 14.8 \\
\hline 1 to 3 years & 108 & 74.3 & 16.6 & 75.7 & 16.4 & 88.1 & 16.4 \\
\hline 3 to 5 years & 61 & 74.5 & 16.4 & 74.7 & 16.2 & 85.3 & 17.6 \\
\hline 5 to 10 years & 101 & 74.9 & 16.0 & 73.6 & 18.3 & 84.6 & 17.4 \\
\hline 10 to 20 years & 74 & 75.8 & 15.0 & 75.8 & 16.5 & 83.3 & 15.5 \\
\hline 20 years or more & 31 & 77.1 & 19.9 & 78.1 & 18.6 & 85.3 & 17.7 \\
\hline$P$ & & \multicolumn{2}{c}{$0.953 \|$} & \multicolumn{2}{c}{$0.725 \|$} & \multicolumn{2}{c}{$0.472 \|$} \\
\hline
\end{tabular}


Table 4 - Cont.

\begin{tabular}{|c|c|c|c|c|c|c|c|}
\hline \multirow{3}{*}{ Variables } & \multicolumn{7}{|c|}{ SAQ* Domains } \\
\hline & \multirow{2}{*}{$\mathbf{N}+$} & \multicolumn{2}{|c|}{ Hospital Management } & \multicolumn{2}{|c|}{ Unit Management } & \multicolumn{2}{|c|}{ Working conditions } \\
\hline & & Mean & SD $\neq$ & Mean & SD $\neq$ & Mean & SD $\neq$ \\
\hline \multicolumn{8}{|c|}{ Chose to work in the unit } \\
\hline Yes & 370 & 75.9 & 15.9 & 76.5 & 16.6 & 86.1 & 16.4 \\
\hline No & 102 & 73.1 & 17.0 & 72.5 & 18.2 & 84.2 & 16.3 \\
\hline P & & \multicolumn{2}{|c|}{$0.122 \S$} & \multicolumn{2}{|c|}{$0.038 \S$} & \multicolumn{2}{|c|}{$0.293 \S$} \\
\hline \multicolumn{8}{|c|}{ Has another employment bond } \\
\hline Yes & 64 & 75.4 & 14.9 & 74.6 & 17.7 & 83.9 & 14.3 \\
\hline No & 409 & 75.2 & 16.4 & 75.7 & 16.9 & 85.9 & 16.7 \\
\hline$P$ & & \multicolumn{2}{|c|}{$0.908 \S$} & \multicolumn{2}{|c|}{$0.651 \S$} & \multicolumn{2}{|c|}{$0.345 \S$} \\
\hline
\end{tabular}

Source: Research data, 2017.

*Safety Attitudes Questionnaire; †N=Total number of participants; FSD=Standard Deviation; §Student's t-test; \#Anova One Way Test - Post Hoc Tukey

\section{DISCUSSION}

The study shows positive results related to patient safety in the reporting institution. In this sense, it is pointed out that in the place investigated, the theme is the agenda of discussions and action plans, considering the return rate of the questionnaire (75\%). Results found in the evaluation of the domains configure a positive security culture. These results converge with some studies conducted in different countries with the same instrument ${ }^{(12-13)}$; however, they differ from the results of the culture assessment in Brazilian research studies, which still is frequently negative.

It is noteworthy that the hospital under study aims to obtain quality certification of health services and passed the first stage of the evaluation in 2016. The positive results are believed to be due to the changes that have been taking place in the service since then. Examples include the implementation of patient safety protocols, the implementation of indicators, the reorganization of routines and the implementation of new training. The aim is to become an institution recognized as having excellent performance by external evaluation, which demands involvement and participation from the professionals in different capacities.

It is known that external evaluation contributes to the development of a positive patient safety culture, since the institution is dedicated to continuously improving care processes, re-/evaluating the results obtained and, thus, seeking way to improve service quality management, which is also through continuing education ${ }^{(12)}$. Therefore, this has certainly influenced the safety culture in the institution and, therefore, reflects on the results of this study.

It is believed that the involvement of the institution workers in this qualification process also contributes to the quality of their actions, as well as to their job satisfaction, which may explain the positive result obtained in the job satisfaction domain, which showed a difference when compared to others. Such results converge with results found in a Brazilian study ${ }^{(14)}$, where this domain is often the one with the best score, unlike professionals from other nationalities ${ }^{(15)}$. It is important to maintain worker involvement, since feeling part of the process makes the worker to act in a committed way, because the result of the institution becomes the result of the employee because the changes/implementations in the company occur with the participations of the employees, and more positively and closer to management ${ }^{(16)}$.

A study conducted in Tunisian hospitals showed that a management action plan is needed to ensure open communication between all team professionals, in equality. This is also necessary to achieve the goal of providing uninterrupted care with the potential to identify patient safety threats, delegate responsibilities to all staff members in order to reduce errors, and ensure continuing training for professionals ${ }^{(17)}$.

We highlight that, in this study, the perception domains of hospital and unit management presented positive scores. This denotes that professionals recognize the work of managers, receive feedback about their performance and that 
staff issues are dealt in a constructively way in both unit management and hospital management. This positive management outcome shows the beginning of patient safety consolidation, because the close relationship between the manager and his team, respect, replacing punishment with collective growth and understanding errors as a system failure are initiatives that strengthen safe care. This result differs from other published studies, where the perception regarding management is unsatisfactory ${ }^{(17-18)}$.

The only domain assessed with scores that were below expected was stress perception, a result that is also found in other patient safety culture surveys ${ }^{(18)}$. The professionals surveyed disagree that their performance is impaired in situations such as excessive workload, physical tiredness and that they are more likely to make mistakes in tense or hostile emergencies when they are tired. Therefore, they do not recognize external factors as possible influencers for the occurrence of AEs. This is a negative aspect, so, it does not contribute to patient safety. Thus, it is necessary for the institution to start the discussion about stressors at work and their possible influence on care outcomes. It is important for the professionals to take ownership of this knowledge/recognition so that they are comfortable with freely expressing their physical or mental stress condition without fear of being punished or discriminated.

The analysis of the scores divided by professional groups showed that the support team, which includes the administrative professionals, obtained positive scores in most domains but, when compared to the other groups (nursing staff and other health professionals), obtained significantly lower mean values in the job satisfaction, teamwork spirit and safe environment domains. These results may point out that the actions aimed at patient safety are still focused only on health professionals, especially those who act directly to patient care. However, individual or only one group effort is not enough to promote patient safety. Rather, a structured objective is required throughout the organization ${ }^{(17)}$.

Overall, the scores of the domains were positive. In addition, there was an association of positive perception regarding the institution's safety culture with variables such as gender, professional qualification, time in the institution and the choice of the unit in which the professional works.

Working women have a better understanding of stress, which indicates that they can better identify the factors that negatively influence their work routine, while men believe that they can develop their work regardless of the adversities they may face. A study conducted in a hospital in Minas Gerais, Brazil, in which there were no significant differences between genders, educational level and the presence of another employment bond in relation to the general score or in each domain ${ }^{(19)}$.

This study showed that qualification is an ally of patient safety, since professionals with higher education achieved better means, which reflects the importance of qualifying workers who provide care, as well as those who manage the service.

The working time at the institution also influenced patient safety. The professionals with one to three years of experience and from five to 10 years had significantly higher mean scores when compared to others, in the teamwork spirit domain $(p<0.015)$. Another study showed a similar relation for the perception of stress and job satisfaction domains associated with having less than six months or more than 20 years of experience. That is, it showed that the professionals newly admitted to the institution better understand the stressors and professionals with more time tend to be more satisfied with the activities they perform ${ }^{(20)}$.

Feeling satisfied with the work can also be influenced by the choice of unit, since the professional identifies with the workplace, which may explain the better perception of the safe atmosphere of the patient in cases where professionals work in the places they chose. In this sense, the hospital management should take into account the preferences of the professionals for the organization of work teams, as situations of dissatisfaction and conflict negatively influence patient safety.

The results of this study show that there may be some advances in the patient safety culture in Brazilian health services. Perhaps these results can be attributed to the policy aimed at improving the quality of assistance implemented since 2013 with the PNSP. Moreover, the efforts of the institution under study are worth mentioning for being in the process of accreditation, a factor that may be determinant for the positive results found in the research.

\section{- CONCLUSION}

From the perspective of all the workers in a large hospital, positive scores were found in all the domains of the safety culture, except for the stress perception domain. The mean of the job satisfaction domain for nursing and other professionals of the multi-professional team was significantly higher when compared to the support team. Other professionals from the multi-professional team obtained a higher mean score, with a significant difference in the teamwork spirit domain, compared to the mean value of the support team. 
Female professionals presented a higher mean score in the Stress perception domain. In contrast, male workers point to higher means in the fields of Unit and Hospital Management. Professionals with greater schooling have a better perception of the domains when compared to the lower levels of education.

Regarding the time of work, workers under three years and those with 10 to 20 years of work had significantly higher scores compared to periods of three to five years and over 20 years. The choice of the professional for his work unit was significantly associated with the high averages in the safe environment, job satisfaction and unit management domains.

Therefore, it is important to emphasize that the assessment of the patient safety culture is an important indicator for health institutions, since it can show in which dimensions institutions need to invest more, carry out planning in order to improve management and care to the patient, reducing AEs. Still, this study contributes greatly to educators of the training courses from the technical to the postgraduate level, managers and health professionals, who should not measure efforts to have a positive culture of security in their institutions, and, consequently, safe care.

This study was conducted in a single institution with specific characteristics, which may constitute a limitation for the generalization of its results. Even so, the analysis of these data contributes to expand the knowledge on this subject, since similar data are not found in the literature. Furthermore, it is suggested that future research studies should be conducted, applying mixed methods, which allow investigating patient safety, considering different factors of the local context.

\section{REFERENCES}

1. Makary MA, Daniel M. Medical error: the third leading cause of death in the US. BMJ. 2016;353:i2139. doi: https://doi.org/10.1136/bmj.i2139

2. Frontier Economics Ltd, London. Exploring the costs of unsafe care in the NHS: a report prepared for the department of health. London: Frontier Ecnonomics;2014 cited 2019 Feb 28. Available from: https://www.frontiereconomics.com/media/2459/exploring-the-costs-of-unsafe-care-in-thenhs-frontier-report-2-2-2-2.pdf

3. Couto RC, Pedrosa TGM, Rosa MB. Erros acontecem: a força da transparência para 0 enfrentamento dos eventos adversos assistenciais em pacientes hospitalizados. Belo Horizonte: Instituto de Saúde Suplementar; 2016 [cited 2019 Feb 28]. Available from: http://documents.scribd.com.s3.amazonaws. com/docs/5x5i1j985c5jwesp.pdf

4. Brazil Ministry of Health (BR). Portaria n 529 , de $1^{\circ}$ de abril de 2013. Institui 0 Programa Nacional de Segurança do Paciente (PNSP). Brasilia (DF); 2013 [cited 2019 Mar 15]. Available from: http://bvsms.saude.gov.br/bvs/saudelegis/ gm/2013/prt0529_01_04_2013.html
5. Morello RT, Lowthian JA, Barker AL, McGinnes R, Dunt D, Brand C. Strategies for improving patient safety culture in hospitals: a systematic review. BMJ Qual Saf. 2013;22(1):11-8. doi: https://doi.org/10.1136/ bmjqs-2011-000582

6. Sexton JB, Helmreich RL, Neilands TB, Rowan K, Vella K, Boyden J, et al. The Safety Attitudes Questionnaire: psychometric properties, benchmarking data, and emerging research. BMC Heal Serv Res. 2006/04/06. 2006;6:44. doi: https://doi.org/10.1186/1472-6963-6-44

7. Thomas A, Lomas JP. Establishing the use of a safety attitudes questionnaire to assess the safety climate across a critical care network. I Intensive Care Soc. 2018;19(3):219-25. doi: https://doi.org/10.1177/1751143717750788

8. Norden-Hagg A, Sexton JB, Kalvemark-Sporrong S, Ring L, Kettis-Lindblad A. Assessing safety culture in pharmacies: the psychometric validation of the Safety Attitudes Questionnaire (SAQ) in a national sample of community pharmacies in Sweden. BMC Clin Pharmacol. 2010;10:8. doi: https://doi. org/10.1186/1472-6904-10-8

9. Carvalho RE, Cassiani SH. Cross-cultural adaptation of the Safety Attitudes Questionnaire - Short Form 2006 for Brazil. Rev Lat-Am Enfermagem. 2012;20(3):575-82. doi: https://doi.org/10.1590/s010411692012000300020

10. Lorenzini E. Cultura de segurança do paciente: estudo com métodos mistos [tese]. Porto Alegre (RS): Programa de Pós-Graduação em Enfermagem, Universidade Federal do Rio Grande do Sul; 2017.

11. Oliveira ICL, Cavalcante MLSN, Aires SF, Freitas RJM, Silva BV, Marinho DMF, et al. Cultura de segurança: percepção dos profissionais de saúde em um hospital mental. Rev Bras Enferm. 2018;71(Suppl 5):2316-22. doi: https://doi. org/10.1590/0034-7167-2018-0125

12. LiY, Zhao X, Zhang X, Zhang C, Ma H, Jiao M, et al. Validation study of the safety attitudes questionnaire $(S A Q)$ in public hospitals of Heilongjiang province, China. PLOS One. 2017;12(6)1-11. doi: https://doi.org/10.1371/journal. pone. 0179486

13. Saraiva DMRF, Almeida AA. Validation of the Safety Attitudes Questionnaire Short Form 2006 to Portugal. Int J Nurs. 2015;2(1):103-12. doi: https://doi. org/10.15640/ijn.v2n1a11

14. Carvalho RE, Arruda LP, Nascimento NK, Sampaio RL, Cavalcante MLSN, Costa ACP. Assessment of the culture of safety in public hospitals in Brazil. Rev Lat-Am Enfermagem. 2017;25:e2849. doi: https://doi.org/10.1590/15188345. 1600.2849

15. Gabrani A, Hoxha A, Simaku A, Gabrani JC. Application of the Safety Attitudes Questionnaire (SAQ) in Albanian hospitals: a cross-sectional study. BMJ Open. 2015;5:e006528. doi: https://doi.org/10.1136/bmjopen-2014-006528

16. Lorenzini E, Oelke ND, Marck PB. Researching safety culture: deliberative dialogue through a restorative lens. Int I Qual Health Care. 2017;29(5):745-9. doi: https://doi.org/10.1093/intahc/mzX080

17. Cheikh AB, Bouafia N, Mahjoub M, Ezzi O, Nouira A, Njah M. Patient's safety culture among Tunisian healthcare workers: results of a cross sectional study in university hospital. Pan Afr Med J. 2016;24:299. doi: https://doi.org/10.11604/ pamj.2016.24.299.8466

18. Kolankiewicz ACB, Loro MM, Schmidt CR, Santos FP, Bandeira VAC, Magnago TSBS. Patient safety climate among nursing staff: contributing factors. Acta Paul Enferm. 2017;30(5):531-7. doi: https://doi.org/10.1590/19820194201700076 
19. Barbosa MH, Floriano DR, Oliveira KF, Nascimento KG, Ferreira LA. Patient safety climate at a private hospital. Texto Contexto Enferm. 2016;25(3)1-8. doi: https://doi.org/10.1590/0104-07072016001460015

20. Luiz RB, Simões ALS, Barichello E, Barbosa MH. Factors associated with the patient safety climate at a teaching hospital. Rev Lat-Am Enfermagem. 2015;23(5):880-7. doi: https://doi.org/10.1590/0104-1169.0059.2627

\section{Acknowledgments:}

To the researched institution, the university and the Institutional Program of Scientific Initiation Scholarships of the National Council for Scientific and Technological Development (CNPQ) for the granting of scholarships.
- Corresponding author:

Adriane Cristina Bernat Kolankiewicz

E-mail: adriane.bernat@unijui.edu.br
Associate editors:

Marta Georgina Oliveira de Goes Cecília Helena Glanzner

\section{Editor-in-chief:}

Maria da Graça Oliveira Crossetti 